\title{
Influence of annual variation in food supply on abundance of wintering common eiders Somateria mollissima
}

\author{
Jesper K. Larsen*, Magella Guillemette** \\ National Environmental Research Institute, Department of Coastal Zone Ecology, Kalø, Grenåvej 12, 8410 Rønde, Denmark
}

\begin{abstract}
We investigated how the annual variation in the abundance of wintering common eiders Somateria mollissima was related to the abundance of benthos over 4 yr. The study was conducted at 2 sites, Tunø Knob and Ringebjerg Sand, Denmark, from 1994 to 1998. Benthos was sampled along permanent transects in November, and common eiders counted and localized from observation towers during the winter. The benthic community was dominated by the blue mussel Mytilus edulis, with sizes varying with depth. Small and intermediary-sized individuals were primarily found in 0 to $6 \mathrm{~m}$ depth, and large individuals exclusively in 6 to $12 \mathrm{~m}$ depth. The pattern of variation in abundance of common eiders matched that of the benthos in 0 to $6 \mathrm{~m}$ depth, where they were mostly found, but not in 6 to $12 \mathrm{~m}$ depth. Based on a bioenergetic model of food consumption, we estimated that common eiders during the 3rd and 4th years exploited between 22 and $64 \%$ of the entire benthic community biomass in 0 to $6 \mathrm{~m}$ depth, compared to $\leq 3 \%$ in 6 to $12 \mathrm{~m}$ depth. We conclude that common eiders tracked annual variation in food abundance, primarily related to the presence of small and intermediary-sized blue mussels.
\end{abstract}

KEY WORDS: Common eider - Abundance $\cdot$ Annual variation $\cdot$ Benthic biomass $\cdot$ Mytilus edulis Food consumption · Prey size

Resale or republication not permitted without written consent of the publisher

\section{INTRODUCTION}

In trying to understand the variation in animal abundance, an intuitive prediction is that more food should attract more consumers. Unless food accessibility is constrained, e.g. by prey size or risk of predation, the abundance of consumers should vary with the temporal and spatial variation of their prey. For birds in the non-breeding season the temporal relationship has been mainly addressed on a shorter time scale, i.e., related to within-season phenology patterns, habitat switching or timing of migration (e.g., Van Eerden 1984, Drent \& Prins 1987, Alonso et al. 1994, Vickery et al. 1995), and only rarely on a longer time scale (Van

Present addresses:

*Carl Bro as, Nordlandsvej 60, 8240 Risskov, Denmark.

E-mail: jln@carlbro.dk

**Département de biologie et sciences de la santé, Université du Québec à Rimouski, 300 allée des Ursulines, Rimouski, Québec, Canada
Eerden 1984, Zwarts et al. 1992). In the case of sea ducks, temporal relationships to food abundance are in general poorly understood, and no studies have addressed the relationship between sea duck abundance and annual variation in food supply.

A complicating factor in the study of the relationship between a predator and its food supply is to precisely define what constitutes potential prey. Common eiders Somateria mollissima are sea ducks that dive repeatedly to secure their benthic prey. Common eiders are reported to exploit a wide range of both prey types (including bivalves, gastropods, crustaceans and echinoderms) and prey sizes (Cottam 1939, Madsen 1954). An apparently preferred prey in the diet of common eiders is the blue mussel Mytilus edulis (Guillemette et al. 1992). It has furthermore been suggested that common eiders prefer blue mussels of smaller sizes (Bustnes \& Erikstad 1990, Guillemette 1998); shell mass increases faster than flesh mass with size in blue mussels, as well as in other marine inverte- 
brates (Rumohr et al. 1987). As common eiders ingest their prey whole, the inorganic content is likely to influence the profitability of a given prey item.

Many benthic prey species are characterized by variable recruitment and high levels of natural mortality arising from predation and physical factors (Beukema 1982, Möller \& Rosenberg 1983, Barnett \& Watson 1986). Consequently, common eiders may face large year-to-year variation in the abundance and composition of prey types and sizes. To demonstrate the influence of annual variation in food supplies on consumer abundance, estimates of predation impact must be provided; if prey is superabundant and the impact of consumers is insignificant, the predictive relationship between the abundance of prey and their consumers is not likely to apply. In this paper, we (1) assess annual variation in abundance of benthic invertebrates and common eiders at 2 sites over $4 \mathrm{yr}$, and (2) estimate food consumption to determine the impact of eider predation on their food supplies.

\section{MATERIALS AND METHODS}

Study area. This study was conducted at 2 sites, Tunø Knob and Ringebjerg Sand, about $15 \mathrm{~km}$ apart in the Århus Bay, southern Kattegat Sea, Denmark (Fig. 1). The study sites are 2 of several shallow areas in the Århus Bay, where up to 80000 eiders Somateria mollissima were counted during the winter seasons from 1994/1995 to 1996/1997 (Guillemette et al. 1998).

The study areas ranged from 0 to $12 \mathrm{~m}$ in depth, and were limited in extent by the distance at which eiders could be surveyed efficiently from observation towers (Fig. 1). At Tunø Knob, observations were conducted from a tower standing on the sea bottom and rising $5 \mathrm{~m}$ above the sea surface. At Ringebjerg Sand, the observation tower was standing on the shore and rose about $15 \mathrm{~m}$ above the sea surface. Due to differences in tower elevation, the observation radius was $1600 \mathrm{~m}$ at Tunø Knob and $2100 \mathrm{~m}$ at Ringebjerg Sand, the total areas of observation being 753 and 719 ha, respectively (Fig. 1). The substrate was dominated by sand with varying amounts of gravel and stones until about 8 to $10 \mathrm{~m}$, below which depth the substrate became increasingly silty. The tidal amplitude in the study region was small $(<0.5 \mathrm{~m})$, hence depths were relatively constant.

Eiders Somateria mollissima were the dominant sea duck, with up to 6000 individuals observed at each study site. In general, numbers build up during October, peak in November/December, and by mid-April only few eiders remain. Other avian benthic predators were the common scoter Melanitta nigra and the velvet scoter $M$. fuscus. However, these species accounted for $<10 \%$ of all individuals observed, and therefore were not considered in this study.

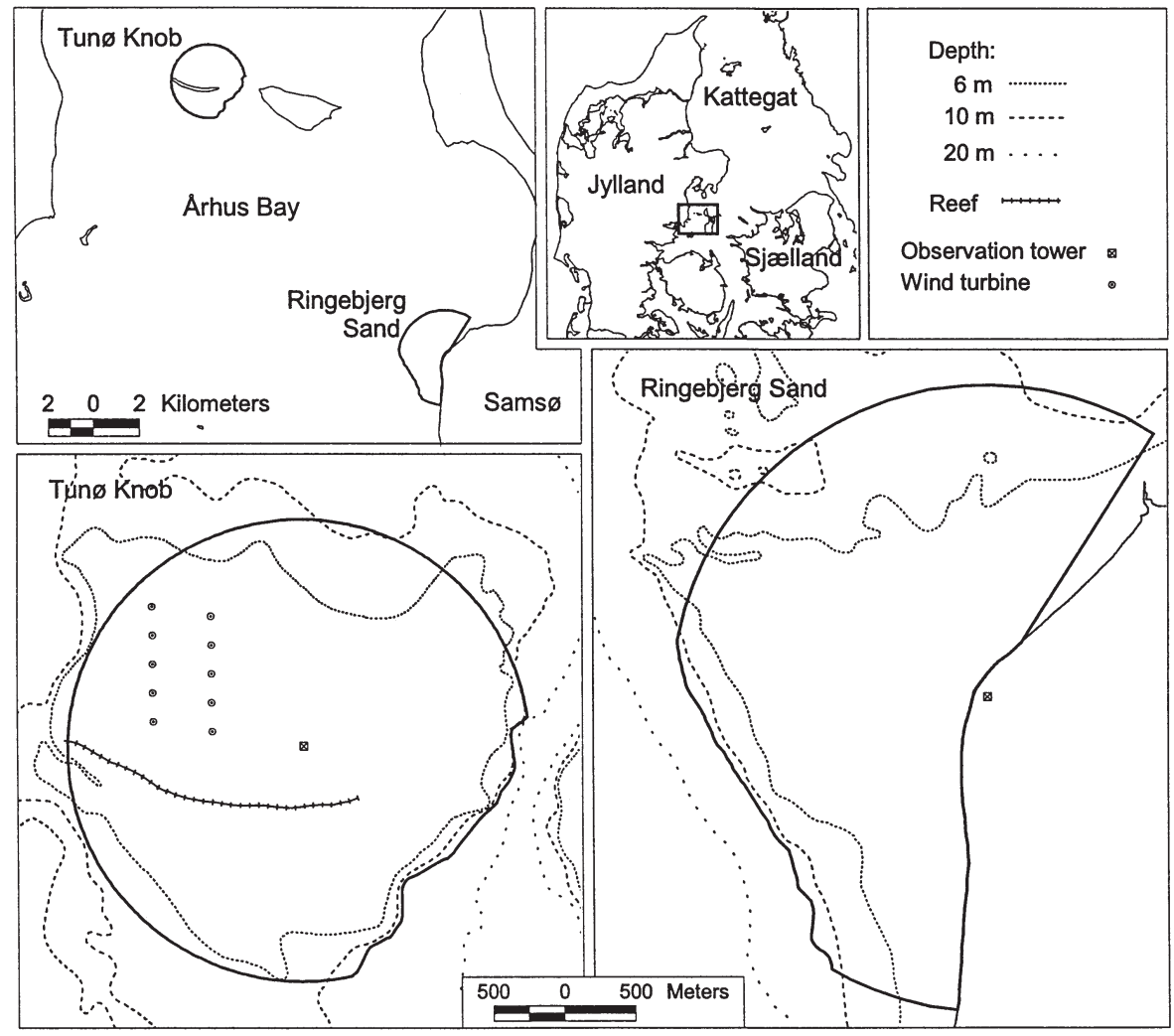

Fig. 1. Study sites and locations in Århus Bay, southern Kattegat Sea, Denmark. Study areas were restricted to 0 to $12 \mathrm{~m}$ depth range within a radius of $1600 \mathrm{~m}$ of the observation tower at Tunø Knob and $2100 \mathrm{~m}$ of the observation tower at Ringebjerg Sand 
Data collection. This study stems from an impactassessment of an offshore wind-turbine park on abundance and distribution of sea ducks, for which a before-after-control-impact design was used (Guillemette et al. 1998). The study extended over 4 winters from 1994/1995 to $1997 / 1998$ at Tunø Knob, and 3 winters from 1994/1995 to 1996/1997 at Ringebjerg Sand. At Tunø Knob, a wind park consisting of ten $500 \mathrm{~kW}$ turbines was constructed during the summer of 1995. Since the impact-assessment study concluded that this wind park affected neither eider abundance nor their spatial distribution (Guillemette et al. 1998), we assumed that it had no influence on the results presented here.

Benthic food supply. The benthic food supply was determined annually by transect-sampling in late November. Three equally spaced transects were established within the 0 to $12 \mathrm{~m}$ depth range, with a northsouth orientation at Tunø Knob and perpendicular to the coast at Ringebjerg Sand. Sampling was carried out at permanent stations (34 at Tunø Knob and 29 at Ringebjerg Sand) positioned at $200 \mathrm{~m}$ intervals along each transect using DGPS (differential global positioning system), with a precision of $10 \mathrm{~m}$. At each station, two $0.04 \mathrm{~m}^{2}$ samples of the top $15 \mathrm{~cm}$ of sediment were dug out by a SCUBA diver. Samples were put in separate bags and frozen for later analysis.

In the laboratory, benthic samples were sieved (mesh size $1 \mathrm{~mm}$ ) and sorted; all individuals $\geq 3 \mathrm{~mm}$ were identified, counted, and their wet mass (WM) obtained. Although eiders have been found to take bivalves as small as $1 \mathrm{~mm}$, the most frequent prey sizes are >3 mm (Madsen 1954). WM was measured for the whole sample and for blue mussels separately. During 1996/1997 and 1997/1998 WM was also obtained for other bivalves, gastropods, echinoderms, crustaceans and polychaetes. Information on sizes (to the nearest millimetre) were obtained for blue mussels by measuring $10 \%$ of all individuals, for other bivalves by measuring all individuals, and for other groups of benthos by measuring the maximum size (except for polychaetes, which were not measured). Because of their large numbers, blue mussels were sub-sampled by spreading the sample evenly in a tray, dividing it into 20 equal parts, and then randomly drawing 2 parts for measurements. The sizes measured were length for bivalves, height for gastropods, arm length for sea stars, and carapace width for crabs.

Since no information on the diet of eiders was collected in our study areas, we will consider 2 scenarios: (1) all benthic species were potential prey, or (2) blue mussels were the only prey.

Eider abundance and distribution. Counts were conducted in the morning, starting $2 \mathrm{~h}$ after sunrise. The location of flocks of $\geq 5$ individuals was deter- mined, taking 1 or more sets of positions with a rangefinder (Zeiss Halem II) and a compass binocular. To determine the depth at which each flock was recorded, data were processed in a GIS (geographic information system) database with detailed bathymetric information (digitised from 1:20000 sea charts).

Observations were grouped in 3 winter periods: early (November/December), mid (January/February) and late (March/mid-April). The temporal relationship between the abundance of eiders and their food supplies was assessed based on the late-winter period, as this was the only period covered in all years at both sites (number of counts ranged between 9 and 18). Estimation of predation impact was based on 2 yr at Tunø Knob, 1996/1997 and 1997/1998, and 1 yr at Ringebjerg Sand, 1996/1997, with counts throughout the winter (5 to 19 period $^{-1}$ ). The number of eiderdays for a full winter cycle was computed by multiplying the mean eider numbers for each period with the number of days and then summing these products for all periods.

For the relationship between eider and food abundance, we assumed that late-winter numbers were representative of the full winter use of study areas. In 1996/1997 and 1997/1998, late-winter numbers varied in accordance with full winter abundance. Furthermore, comparison of late- and early-winter use over a period of $3 \mathrm{yr}$, including data from additional counts in early winter 1995/1996, revealed a significant correlation (Spearman's rank correlation, $\mathrm{r}_{\mathrm{s}}=0.900, \mathrm{p}=0.050$, $\mathrm{n}=5$ ).

Exploitation of food resources. The proportion of food consumed by eiders over a complete winter cycle (the exploitation rate) was estimated from the available biomass of prey and a bioenergetic model of food consumption. The available biomass of different prey types was converted into energy equivalents using conversion factors based on WM or, in the case of blue mussels, shell-free dry mass (SFDM). For blue mussels we calculated SFDM, as this was the most abundant prey and the prey with the largest range of sizes, based on its size-frequency distribution and the allometrical relationship between size and SFDM derived at the study sites in November 1994 and 1995: ln SFDM = $-12.2111+3.0093 \times \ln$ length $\left(R^{2}=0.99, n=111\right)$. The energy content of blue mussel biomass was calculated using $21.19 \mathrm{~kJ} \mathrm{~g}^{-1}$ SFDM as the conversion factor, based on mean values reported by Rumohr et al. (1987). For other types of prey we used the following conversion factors, taken from Rumohr et al.: other bivalves, $1.24 \mathrm{~kJ} \mathrm{~g}^{-1} \mathrm{WM}$ (based on Cardium fasciatus, the dominant species); gastropods, $1.75 \mathrm{~kJ} \mathrm{~g}^{-1} \mathrm{WM}$ (mean for the taxa); echinoderms, $2.26 \mathrm{~kJ} \mathrm{~g}^{-1} \mathrm{WM}$ (the value for Asterias spp., the dominant species); and polychaetes, $2.90 \mathrm{~kJ} \mathrm{~g}^{-1} \mathrm{WM}$ (mean for the taxa). We 
assumed that the weight of individual prey did not increase during winter (Kautsky 1982, Craeymeersch et al. 1986, Honkoop \& Beukema 1997), and considered that only a reduction in abundance and biomass is likely to occur during that period.

Full winter energy-consumption of common eiders was estimated from the model: energy consumed = number of bird-days $\times$ (field metabolic rate [FMR]/ energy assimilation rate). Daily energy requirements were calculated using the equation for FMR of sea birds given by Nagy (1987), where log FMR $\left(\mathrm{J} \mathrm{d}^{-1}\right)=$ $0.904+0.704 \times$ body mass $(\mathrm{g})$. For body mass, a value of $2300 \mathrm{~g}$ was used based on weights of common eiders wintering in the Kattegat (K. Laursen unpubl. data). An assimilation rate of 0.85 was used, based on De Leeuw's (1997) study of tufted ducks Aythya fuligula feeding on zebra mussels Dreissena polymorpha. Confidence intervals could not be applied to exploitationrate estimates as no analytical tools for simultaneously taking into account the variation of several model variables were available.

Data analysis. Annual differences in benthic food abundance were assessed based on stations as sampling units, taking the mean of sub-samples. Temporal variation was then tested using 2-way ANOVA on log $(\mathrm{n}+1)$-transformed data, with years as repeated measures.

Since counts of eiders during the late-winter period were highly autocorrelated (Guillemette et al. 1998), it was not possible to test between-year differences using ANOVA. Instead, we used confidence intervals based on a low nominal alpha level. The use of low alpha levels was proposed by Hatfield et al. (1996) as a means of mitigating any impacts of serial correlation. Therefore, we used an alpha level of 0.01 to calculate confidence intervals. With the sample sizes and the level of autocorrelation found by Guillemette et al., an alpha level of 0.01 corresponds approximately to a real alpha level of 0.10 (see Stewart-Oaten et al. 1992). Differences between years were inferred when the mean of numbers in one year was not included in the confidence interval of another year. Although approximate, this was considered the best method with the data at hand.

\section{RESULTS}

\section{Benthic food supply}

The composition of the benthic community is shown in Table 1, based on mean densities in 1994/1995 and 1996/1997, representing years of high and low food abundance, respectively. At both sites, bivalves were the most abundant group of prey, comprising $98 \%$ of all individuals in 1994/1995 and 72 to $78 \%$ in 1996/ 1997. The blue mussel Mytilus edulis was the most abundant species, with 11000 to 14000 ind. $\mathrm{m}^{-2}$ in

Table 1. Composition of benthic community in terms of absolute (ind. $\mathrm{m}^{-2}$ ) and relative (\%) density during 1994/1995 and 1996/1997, years of high and low food abundance, respectively, at Tunø Knob and Ringebjerg Sand

\begin{tabular}{|c|c|c|c|c|c|c|c|c|}
\hline \multirow{3}{*}{$\begin{array}{l}\text { Prey group } \\
\text { Species }\end{array}$} & \multicolumn{4}{|c|}{ Tunø Knob } & \multicolumn{4}{|c|}{ Ringebjerg Sand } \\
\hline & \multicolumn{2}{|c|}{ 1994/1995 } & \multicolumn{2}{|c|}{ 1996/1997 } & \multicolumn{2}{|c|}{$1994 / 1995$} & \multicolumn{2}{|c|}{ 1996/1997 } \\
\hline & (ind. $\mathrm{m}^{-2}$ ) & $(\%)$ & (ind. $\mathrm{m}^{-2}$ ) & $(\%)$ & (ind. $\mathrm{m}^{-2}$ ) & $(\%)$ & (ind. $\mathrm{m}^{-2}$ ) & $(\%)$ \\
\hline Bivalves & 11539 & $(98.3)$ & 189 & $(77.6)$ & 14619 & (98.1) & 117 & $(72.0)$ \\
\hline Mytillus edulis & 11111 & $(94.7)$ & 100 & $(41.0)$ & 14382 & $(96.5)$ & 78 & $(47.6)$ \\
\hline Cardium spp. & 202 & $(1.7)$ & 60 & $(24.4)$ & 118 & $(0.8)$ & 20 & $(12.2)$ \\
\hline Mya arenaria & 144 & $(1.2)$ & 6 & $(2.4)$ & 74 & $(0.5)$ & 5 & $(2.9)$ \\
\hline Macoma spp. & 24 & $(0.2)$ & 7 & $(2.7)$ & 21 & $(0.1)$ & 6 & $(3.7)$ \\
\hline Spisula subtruncata & 10 & $(0.1)$ & 10 & $(4.2)$ & 0 & $(0.0)$ & 1 & $(0.5)$ \\
\hline Others & 47 & $(0.4)$ & 7 & $(2.8)$ & 24 & $(0.2)$ & 8 & $(5.0)$ \\
\hline Gastropods & 44 & $(0.4)$ & 14 & $(5.7)$ & 22 & $(0.1)$ & 9 & $(5.6)$ \\
\hline Littorina littorea & 11 & $(0.1)$ & 4 & $(1.7)$ & 16 & $(0.1)$ & 9 & $(5.6)$ \\
\hline Acmaea testudinalis & 22 & $(0.2)$ & 10 & $(4.1)$ & 6 & $(0.0)$ & 0 & $(0.0)$ \\
\hline Others & 10 & $(0.1)$ & 0 & $(0.0)$ & 0 & $(0.0)$ & 0 & $(0.0)$ \\
\hline Echinoderms & 76 & $(0.6)$ & 6 & $(2.4)$ & 98 & $(0.7)$ & 9 & $(5.3)$ \\
\hline Asterias rubens & 56 & $(0.5)$ & 3 & $(1.2)$ & 64 & $(0.4)$ & 6 & $(4.0)$ \\
\hline Echinocyanus pusilus & 13 & $(0.1)$ & 1 & $(0.3)$ & 8 & $(0.1)$ & 1 & $(0.8)$ \\
\hline Others & 8 & $(0.1)$ & 2 & $(0.8)$ & 26 & $(0.2)$ & 0 & $(0.0)$ \\
\hline Crustaceans & 21 & $(0.2)$ & 10 & (3.9) & 20 & $(0.1)$ & 10 & (6.1) \\
\hline Carcinus maenas & 2 & $(0.0)$ & 2 & $(0.9)$ & 4 & $(0.0)$ & 2 & $(1.1)$ \\
\hline Others & 19 & $(0.2)$ & 7 & $(3.0)$ & 16 & $(0.1)$ & 8 & $(5.0)$ \\
\hline Polychaetes & 46 & $(0.4)$ & 25 & $(10.4)$ & 119 & $(0.8)$ & 15 & (9.3) \\
\hline Others & 8 & $(0.1)$ & 0 & $(0.0)$ & 19 & $(0.1)$ & 3 & (1.9) \\
\hline
\end{tabular}


1994/1995 and 100 to 200 ind. $\mathrm{m}^{-2}$ in 1996/1997, representing 95 to 97 and 41 to $48 \%$, respectively, of all benthic individuals. Other bivalves commonly found were Cardium spp. and Mya arenaria, with densities varying between 5 and 202 ind. $\mathrm{m}^{2}$. None of the other groups (gastropods, echinoderms, crustaceans and polychaetes) made up $>10 \%$ of all individuals (Table 1 ). Except for blue mussels and the sea star Asterias rubens, the sizes of the most abundant benthic prey species were all $<35 \mathrm{~mm}$. Amongst the sea stars, only a small fraction of the individuals were $>35 \mathrm{~mm}$.

In terms of overall biomass the blue mussel was clearly the dominant species, accounting for 93 to $99 \%$ of the total benthic biomass at Tunø Knob over 4 yr, and 79 to $95 \%$ at Ringebjerg Sand over 3 yr. Blue mussels were found throughout the 0 to $12 \mathrm{~m}$ depth range, but with a marked difference in the distribution of size classes (Fig. 2). In general, 3 size classes of mussels could be discerned. At Tunø Knob, small (median length $<10 \mathrm{~mm}$ ), and large-sized (median length 50 to $70 \mathrm{~mm}$ ) blue mussels were found, whereas at Ringebjerg Sand, small and intermediate-sized (median length 20 to $40 \mathrm{~mm}$ ) mussels were found. At Tunø Knob, small blue mussels were found throughout the depth gradient, but occurred mostly at $<7 \mathrm{~m}$ depth, whereas large blue mussels were found exclusively between 6 and $12 \mathrm{~m}$ depth (Fig. 2). At Ringebjerg Sand, small blue mussels were found throughout the depth gradient, but occurred most frequently at $<6 \mathrm{~m}$ depth, whereas medium-sized blue mussels were found exclusively between 0 and $6 \mathrm{~m}$ depth. Based on this, we subdivided the benthic community into the 0 to $6 \mathrm{~m}$ and the 6 to $12 \mathrm{~m}$ depth range, making up 82 and $18 \%$, respectively, of the study area at Tunø Knob, and 64 and 36\%, respectively, at Ringebjerg Sand.

The benthic food supply differed markedly between depths, with the highest biomass in 6 to $12 \mathrm{~m}$ depth at Tunø Knob and 0 to $6 \mathrm{~m}$ depth at Ringebjerg Sand (Fig. 3), mainly reflecting the incidence of larger blue mussels. Within depth ranges, the total benthic biomass differed markedly between years (Fig. 3). At Tunø Knob, the mean benthic biomass in 0 to $6 \mathrm{~m}$ depth decreased from $0.7 \mathrm{~kg} \mathrm{WM} \mathrm{m}^{-2}$ in 1994/1995 to $<0.1 \mathrm{~kg} \mathrm{WM} \mathrm{m}^{-2}$ in 1996/1997, and then increased again to $0.4 \mathrm{~kg} \mathrm{WM} \mathrm{m}^{-2}$ in 1997/1998 ( $F_{3,54}=5.631, \mathrm{p}=$ 0.002). In 6 to $12 \mathrm{~m}$ depth, the decrease in mean benthic biomass from $8.0 \mathrm{~kg} \mathrm{WM} \mathrm{m}^{-2}$ in 1994/1995 to $2.4 \mathrm{~kg} \mathrm{WM} \mathrm{m}^{-2}$ in $1997 / 1998$ was not significant $\left(F_{3,42}=\right.$ $1.326, \mathrm{p}=0.278$ ). For both depth ranges, these patterns reflected the variation in the abundance of blue mussels, constituting the majority of the biomass (Fig. 3); the variation in blue mussel biomass was significant in 0 to $6 \mathrm{~m}$ depth $\left(F_{3,54}=4.849, \mathrm{p}=0.005\right)$ but not in 6 to $12 \mathrm{~m}$ depth $\left(F_{3,42}=1.350, \mathrm{p}=0.271\right)$.
Tunø Knob

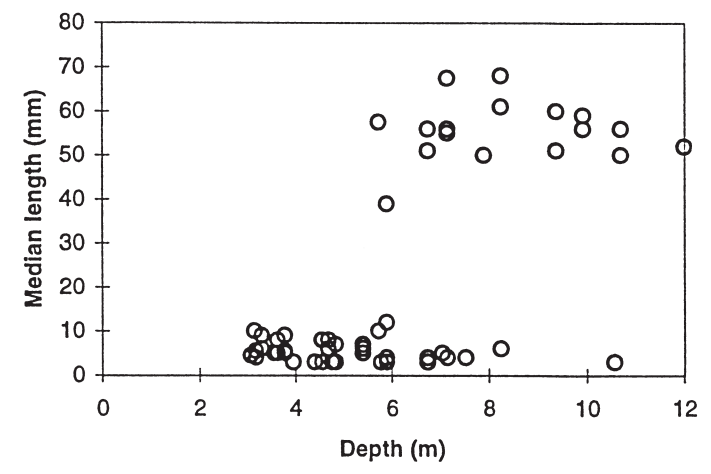

Ringebjerg Sand

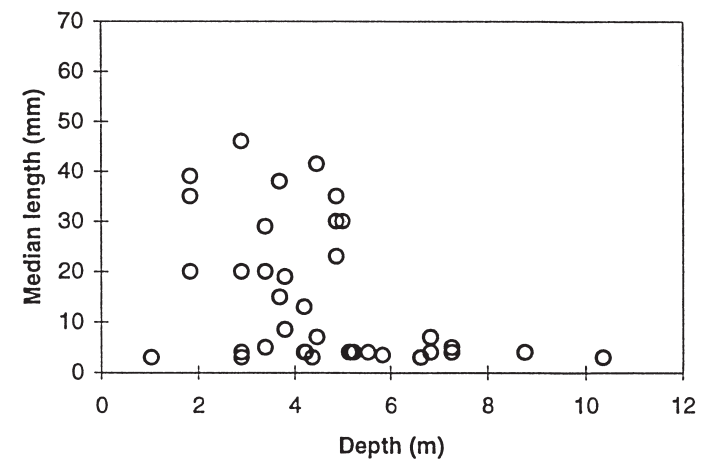

Fig. 2. Mytilus edulis. Median length at benthic sampling stations in relation to water depth combined for 4 winters at Tunø Knob and 3 winters at Ringebjerg Sand. Sampling was done at 34 permanent stations at Tunø Knob and 29 at Ringebjerg Sand in late November each year

At Ringebjerg Sand, mean benthic biomass in 0 to 6 m depth was $\sim 5.5 \mathrm{~kg} \mathrm{WM} \mathrm{m}^{-2}$ in both 1994/1995 and $1995 / 1996$ and then declined to $0.4 \mathrm{~kg} \mathrm{WM} \mathrm{m}^{-2}$ in 1996/1997 $\left(F_{2,42}=3.819, \mathrm{p}=0.030\right.$, Fig. 3). In 6 to $12 \mathrm{~m}$ depth, the decline from $0.9 \mathrm{~kg} \mathrm{WM} \mathrm{m}^{-2}$ in 1994/1995 to $0.1 \mathrm{~kg} \mathrm{WM} \mathrm{m}^{-2}$ in 1996/1997 was not significant $\left(F_{2,12}=\right.$ $1.579, \mathrm{p}=0.246$ ). Similar to Tunø Knob, the pattern of variation of benthos abundance at Ringebjerg Sand reflected variation in blue mussel biomass (Fig. 3); blue mussel biomass decreased significantly in 0 to $6 \mathrm{~m}$ depth from 1994/1995 to 1996/1997 $\left(F_{2,42}=3.957, \mathrm{p}=\right.$ $0.027)$, but not in 6 to $12 \mathrm{~m}$ depth $\left(F_{2,12}=2.527, \mathrm{p}=\right.$ $0.121)$.

\section{Eider Somateria mollissima abundance}

The annual variation in eider numbers within the 2 depth ranges is shown in Fig. 4a. We inferred statistical significant difference between years when the mean number of eiders of one particular year was not included in the confidence intervals of another year 


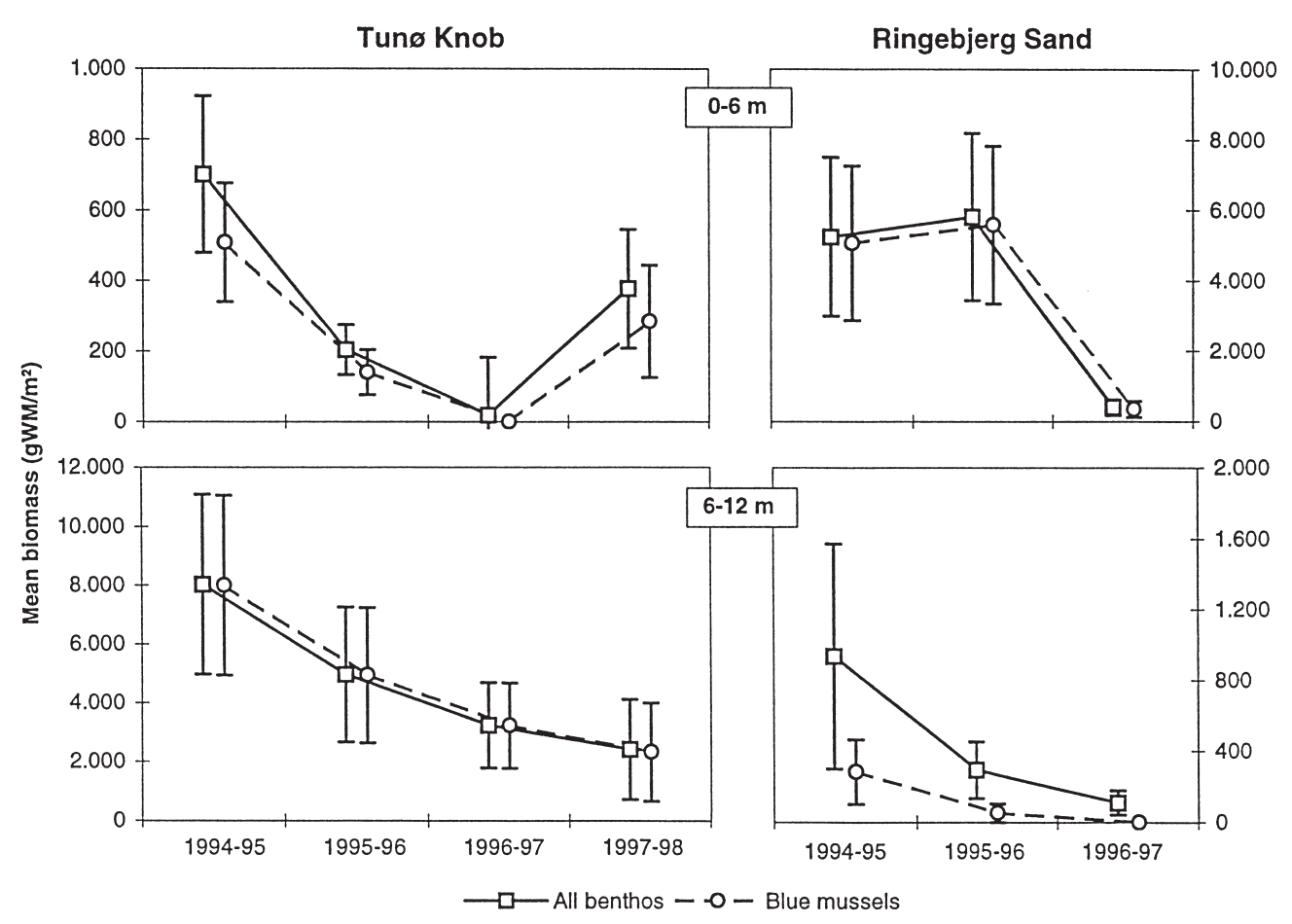

Fig. 3. Inter-annual variation in food biomass (mean wet mass, WM, \pm SE) at Tunø Knob and Ringebjerg Sand in 2 depth ranges, 0 to 6 and 6 to $12 \mathrm{~m}$, for all benthos and for blue mussels only. Number of stations at Tunø Knob was 19 in the 0 to $6 \mathrm{~m}$ and 15 in the 6 to $12 \mathrm{~m}$ depth range, and at Ringebjerg Sand 22 in the 0 to $6 \mathrm{~m}$ and 7 in the 6 to $12 \mathrm{~m}$ depth range. Note different scales of ordinates

(see 'Materials and methods; Data analysis'). At Tunø Knob, mean numbers in the 0 to $6 \mathrm{~m}$ depth range declined from 2005 individuals in 1994/1995 to 443 individuals in 1996/1997, and then increased again to 3243 individuals in 1997/1998; all differences between consecutive years were significant. In the 6 to $12 \mathrm{~m}$ depth range, eider numbers increased from 105 individuals in 1994/1995 to 269 individuals in 1995/1996, then decreased to 11 individuals in 1996/1997 to increase again to 285 individuals in 1997/1998; all differences between consecutive years were significant. At Ringebjerg Sand, the mean numbers in 0 to $6 \mathrm{~m}$ depth, were similar in 1994/1995 and 1995/1996, with 2191 and 2771 individuals, respectively, and then decreased significantly to 1537 individuals in 1996/ 1997. In 6 to $12 \mathrm{~m}$ depth, mean numbers, ranging between 6 and 45 individuals, did not differ significantly between years.

Since depth ranges differed in surface area, we converted common eider numbers into densities to compare depth use (Fig. 4b). At Tunø Knob, the density of common eiders was higher in 0 to $6 \mathrm{~m}$ depth than in 6 to 12 m depth, except for 1995/1996 when densities were similar. At Ringebjerg Sand, the density of common eiders was higher in 0 to $6 \mathrm{~m}$ depth for all years.

\section{Food and eider abundance}

In 0 to $6 \mathrm{~m}$ depth, mean common eider numbers showed annual fluctuations similar to those in food biomass, whether prey was considered to be all benthos or blue mussels only. This was true for Tunø Knob, where food and eider abundance decreased concurrently during the first $3 \mathrm{yr}$ and then increased in the 4 th year, and for Ringebjerg Sand, where food and eider abundance were similar during the first $2 \mathrm{yr}$ and then decreased in the 3 rd year (Figs. 3 \& 4). Combining the data for the 2 sites, eider densities were significantly positively correlated with total benthic biomass $\left(\mathrm{r}_{\mathrm{s}}=\right.$ 0.857, $\mathrm{p}=0.036, \mathrm{n}=7$ ) as well as blue mussel biomass $\left(\mathrm{r}_{\mathrm{s}}=0.893, \mathrm{p}=0.007, \mathrm{n}=7\right)$.

For 6 to $12 \mathrm{~m}$ depth, eider abundance did not fluctuate with annual variation in food supply (Figs. $3 \& 4$ ). The density of eiders for that depth range was not correlated with total benthic biomass $\left(r_{s}=0.500, p=0.253, n=7\right)$, nor with blue mussel biomass $\left(r_{s}=0.429, p=0.294, n=7\right)$.

\section{Food exploitation rates}

To determine if fluctuations in common eider abundance were related to exhaustion of food resources, we 

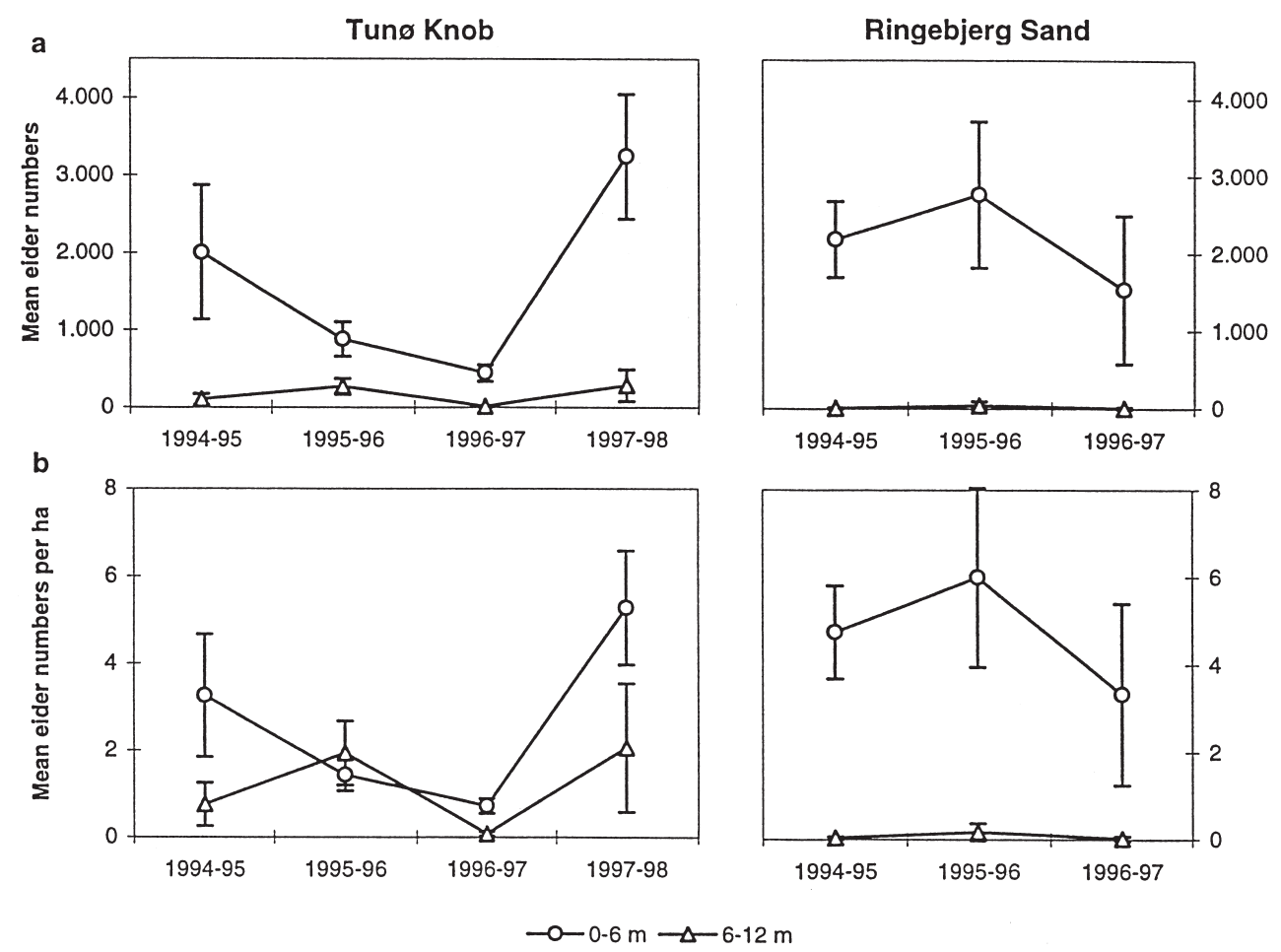

Fig. 4. Somateria mollissima. Annual variation in common eider abundance in late winter (March/mid-April) in terms of (a) mean absolute numbers, and (b) mean density at Tunø Knob and Ringebjerg Sand for the 2 depth ranges, 0 to 6 and 6 to $12 \mathrm{~m}$. Values are means with $\sim 90 \%$ confidence intervals (see 'Materials and methods; Data analysis' for details)

used a bioenergetic model to estimate the amount of food supply consumed considering 2 scenarios: (1) all benthic species were prey to the eiders, and (2) blue mussels were the only prey (see 'Materials and methods; Benthic food supply'). In 0 to $6 \mathrm{~m}$ depth at Tunø Knob in 1996/1997, a winter characterized by low food abundance and the absence of blue mussels, the over- all level of exploitation for the whole benthic community was $64 \%$ (Table 2). For bivalves, we estimated an exploitation rate of $>100 \%$, suggesting that common eiders would have had to be sustained mainly on nonbivalve prey. In 1997/1998, we estimated exploitation rates of $38 \%$ for all benthic species and $58 \%$ for blue mussels only. At Ringebjerg Sand in 1996/1997, com-

Table 2. Somateria mollissima. Availability of food, consumption and exploitation rates for years with known full-winter bird use at Tunø Knob and Ringebjerg Sand for 2 depth ranges, 0 to 6 and 6 to $12 \mathrm{~m}$. Exploitation rates was estimated from food requirements of eiders, using a bioenergetic model and the energy value of potential food supply (see 'Materials and methods; Exploitation of food resources'). In 1996/1997, in the 0 to $6 \mathrm{~m}$ depth range at Tunø Knob and the 6 to $12 \mathrm{~m}$ depth range at Ringebjerg Sand, blue mussels (B. mussels) were absent, and therefore exploitation rates could not be calculated (-)

\begin{tabular}{|c|c|c|c|c|c|c|}
\hline \multirow{2}{*}{$\begin{array}{l}\text { Depth } \\
\text { (m) }\end{array}$} & \multirow[t]{2}{*}{ Year } & \multicolumn{2}{|c|}{ Availability of food } & \multirow{2}{*}{$\begin{array}{l}\text { Consumption } \\
\left(\mathrm{kJ} \mathrm{m}^{-2}\right)\end{array}$} & \multicolumn{2}{|c|}{ Food exploitation } \\
\hline & & $\begin{array}{l}\text { All benthos } \\
\left(\mathrm{kJ} \mathrm{m}^{-2}\right)\end{array}$ & $\begin{array}{l}\text { B. mussels } \\
\left(\mathrm{kJ} \mathrm{m}^{-2}\right)\end{array}$ & & $\begin{array}{c}\text { All benthos } \\
(\%)\end{array}$ & $\begin{array}{c}\text { B. mussels } \\
(\%)\end{array}$ \\
\hline \multicolumn{7}{|c|}{ Tunø Knob } \\
\hline 0 to 6 & $\begin{array}{l}1996 / 1997 \\
1997 / 1998\end{array}$ & $\begin{array}{r}44 \\
378\end{array}$ & $\begin{array}{r}0 \\
246\end{array}$ & $\begin{array}{r}26 \\
145\end{array}$ & $\begin{array}{l}64 \\
38\end{array}$ & $\frac{-}{58}$ \\
\hline 6 to 12 & $\begin{array}{l}1996 / 1997 \\
1997 / 1998\end{array}$ & $\begin{array}{l}4243 \\
3262\end{array}$ & $\begin{array}{l}4214 \\
3095\end{array}$ & $\begin{array}{r}2 \\
22\end{array}$ & $\begin{array}{r}<0.1 \\
1\end{array}$ & $\begin{array}{r}<0.1 \\
1\end{array}$ \\
\hline \multicolumn{7}{|c|}{ Ringebjerg Sand } \\
\hline 0 to 6 & 1996/1997 & 624 & 512 & 134 & 22 & 25 \\
\hline 6 to 12 & 1996/1997 & 83 & 0 & 2 & 3 & - \\
\hline
\end{tabular}


mon eiders would have consumed $22 \%$ of the total benthic biomass in 0 to $6 \mathrm{~m}$ depth, or $25 \%$ of the blue mussel biomass. Finally, in 6 to $12 \mathrm{~m}$ depth, common eiders in both study areas exploited only a negligible part of the food biomass, i.e. $\leq 1 \%$ at Tunø Knob and $3 \%$ at Ringebjerg Sand (Table 2 ).

\section{DISCUSSION}

All benthic species sampled in our study areas can be considered as potential prey, since most species are known to be taken by the common eider (Cottam 1939, Madsen 1954). Moreover, this statement also applies to the sizes of prey found, as the maximum size of most benthic species is below $80 \mathrm{~mm}$, which corresponds to the maximum size of prey eaten by the common eider (Cottam 1939, Madsen 1954).

In both study areas, the highest concentrations of common eiders were found at shallow depths, corresponding with what is generally reported in the literature (Stott \& Olson 1973, Guillemette et al. 1993, Bustnes \& Lønne 1997). For hard bottoms, the concentration of sea ducks in shallow waters has been suggested to reflect a general negative relationship between benthic biomass and depth (reviewed by Guillemette et al. 1993). At Ringebjerg Sand, the benthic food biomass was indeed highest in the shallow parts, but at Tunø Knob biomass was markedly greater in the deeper parts. Therefore, the present results suggest that for sandy and soft bottoms the presence of sea ducks in shallow waters cannot be seen as a simple reflection of the benthic biomass.

Since the time (and energy) spent travelling between the bottom and the surface is likely to be higher at 6 to $12 \mathrm{~m}$ depth compared to 0 to $6 \mathrm{~m}$ depth (Ydenberg \& Guillemette 1991), an alternative factor underlying the observed pattern of depth use might be diving costs. Indeed, eiders at Tunø Knob preferred to dive in shallow waters (0 to $6 \mathrm{~m}$ ), despite 10-fold higher benthic biomass in deeper waters ( 6 to $12 \mathrm{~m}$; Figs. $3 \& 4$ ). This was true even when very low prey densities and complete absence of blue mussels Mytilus edulis occurred in shallow waters in 1996/1997. Apart from diving costs, digestion and processing of hard-shelled molluscs may be another important component of feeding costs in this species (Guillemette 1998). In deeper waters at Tunø Knob, large-sized blue mussels dominated the benthic biomass. Since blue mussel shellmass increases with size faster than the flesh mass, feeding on large blue mussels would be less profitable, as more shell material needs to be processed. In a study from northern Norway, Bustnes \& Erikstad (1990) found that eiders would have to process $1.5 \mathrm{~kg}$ of shells each day when feeding on mussels $<25 \mathrm{~mm}$ in length compared to $\sim 2.5 \mathrm{~kg}$ when eating mussels of $\sim 40 \mathrm{~mm}$ in length. We suggest that the large-sized blue mussels, found at 6 to $12 \mathrm{~m}$ depth, were not profitable prey to common eiders. It follows that processing large-sized mussels at Tunø Knob would add to the higher diving costs associated with greater depths. It is thus difficult to interpret the pattern of depth use at Tunø Knob. Nevertheless, 6 to $12 \mathrm{~m}$ are well within the diving capabilities of this species as large numbers of common eiders in the Århus Bay feed at depths between 6 and $20 \mathrm{~m}$ (J.K.L. \& M.G. pers. obs.), and common eiders are known to dive at depths of 25 to 45 m (Brun 1971, Guillemette et al. 1993).

The considerable annual fluctuations in abundance of the benthic food supply at 0 to $6 \mathrm{~m}$ depth was closely reflected in the pattern of abundance of common eiders. Since the pattern of variation in common eider abundance differed between the 2 study sites, this relationship could not have resulted from general variation in regional numbers. The common eiders seemed to consume a large proportion of the total benthic food supply in the 0 to $6 \mathrm{~m}$ depth range in both years and study sites considered (22 to $64 \%$ for all benthos or 25 to $58 \%$ for blue mussels only), supporting the contention that the abundance of common eiders was related to the annual variation in food supplies. Guillemette et al. (1996) found comparable exploitation rates (48 to $69 \%$ ) for common eiders feeding mainly on smallsized blue mussels. Nilsson (1980) and Nehls (1989) reported much lower exploitation rates for common eiders ( 7 and $13 \%$, respectively); however, their studies estimated food consumption at large spatial scales, which were likely to include areas or food resources not used by the birds. In 6 to $12 \mathrm{~m}$ depth in the present study, benthic food supplies varied less markedly than in the 0 to $6 \mathrm{~m}$ depth range. At both sites, the observed trend for a gradual decline in food biomass at 6 to $12 \mathrm{~m}$ depth was not reflected in the abundance of common eiders, and the estimated overall exploitation rates were correspondingly small (0 to $3 \%$ ).

The relationship between abundance of common eiders and their overall potential food supply at 0 to $6 \mathrm{~m}$ depth also applied when blue mussels were considered to be the sole prey, as they made up the majority of the potential prey biomass. However, common eiders could not have subsisted entirely on a diet of blue mussels in all years. In 1996/1997 at Tunø Knob, common eiders were still present in the shallow areas, despite the absence of blue mussels. Our estimates of food consumption suggest that common eiders would have subsisted mainly on a non-bivalve diet that winter. Thus, it seems likely that the diet of common eiders changes radically between years.

The annual variability in blue mussel abundance observed in this study was related to a combination of 
highly variable recruitment (high the 1st year, lacking during the 2 subsequent years and moderate in the 4 th year) and high natural mortality from predation (attributable to common eiders, as well as other benthic predators such as sea stars). Similarly variable annual recruitment patterns have been reported for other potential benthic prey of eiders (Beukema 1982, Möller \& Rosenberg 1983, Barnett \& Watson 1986). Thus, annual variability in abundance and composition of benthic prey types may be a common feature of the shallow water feeding grounds of wintering common eiders. With this background, large-scale 'sampling' of food supplies, as suggested by the observed tracking of local food abundance, in combination with a generalized diet, seem likely and highly adaptional traits of overwintering common eiders.

Acknowledgements. We wish to thank several anonymous referees, and Tony Fox and Preben Clausen for valuable suggestions on improving the manuscript. The presented data were collected as part of an EIA study on an offshore wind park, financed jointly by the energy consortium ELSAM, the Energy Agency, the Forest and Nature Agency and the National Environmental Research Institute of Denmark.

\section{LITERATURE CITED}

Alonso JC, Alonso JA, Bautista LM (1994) Carrying capacity of staging areas and facultative migration extension in common cranes. J Appl Ecol 31:212-222

Barnett PRO, Watson J (1986) Long term changes in some benthic species in the Firth of Clyde, with particular reference to Tellina tenuis da Costa. Proc R Soc Edinb (Sect B) 90:287-302

Beukema JJ (1982) Annual variation in reproductive success and biomass of the major macrozoobenthic species living in a tidal flat area of the Wadden Sea. Neth J Sea Res 16: $37-45$

Brun E (1971) Predation of Chlamys islandica (O.F. Müller) by Eiders Somateria spp. Astarte 4:23-29

Bustnes JO, Erikstad KE (1990) Mussel size selection in the Common eider: energy maximization or weight minimization. Can J Zool 68:2280-2283

Bustnes JO, Lønne OJ (1997) Habitat partitioning among sympatric wintering common eiders Somateria mollisima and king eiders Somateria spectabilis. Ibis 139:549-554

Cottam C (1939) Food habits of North American diving ducks. Tech Bull US Dep Agricul 643

Craeymeersch JA, Herman PMJ, Meire PM (1986) Secondary production of an intertidal mussel (Mytilus edulis) population in the eastern Scheldt (S.W. Netherlands). Hydrobiologia 133:107-115

Drent RH, Prins HHT (1987) The herbivore as a prisoner of its food supply. In: van Andel J, Bakker JP, Snaydon RW (eds) Disturbance in grasslands. Junk, Dordrecht, p 131-147

De Leeuw JJ (1997) Demanding divers. Ecological energetics of food exploitation by diving ducks. Van Zee tot Land 61, Rijkwaterstaat Directorate Ijsselmeergebied, Lelystad; $\mathrm{PhD}$ thesis, University of Groningen

Editorial responsibility: John Austin (Assistant Editor), Oldendorf/Luhe, Germany
Guillemette M (1998) The effect of time and digestion constraints in Common Eiders while feeding and diving over blue mussel beds. Funct Ecol 12:123-131

Guillemette M, Ydenberg RC, Himmelman JH (1992) The role of energy intake in prey and habitat selection of common eiders in winter: a risk-sensitive interpretation. J Anim Ecol 61:599-610

Guillemette M, Himmelman JH, Barette C, Reed A (1993) Habitat selection by common eiders in winter and its interaction with flock size. Can J Zool 71:1259-1266

Guillemette M, Reed A, Himmelman JH (1996) Availability and consumption of food by common eiders wintering in the Gulf of St. Lawrence: evidence of prey depletion. Can J Zool 74:32-38

Guillemette M, Larsen JK, Clausager I (1998) Impact assessment of an off-shore wind park on sea ducks. The National Environmental Research Institute, Ministry of Environment, Copenhagen (Tech Rep no. 209)

Hatfield JS, Gould WR, Hoover BA, Fuller MR, Lindquist EL (1996) Detecting trends in raptor counts: power and type I error rates of various statistical tests. Wildl Soc Bull 24: 505-515

Honkoop PJC, Beukema JJ (1997) Loss of body mass in winter in three intertidal bivalve species: an experimental and observational study of the interacting effects between water temperature, feeding time and feeding behaviour. J Exp Mar Biol Ecol 212:277-297

Kautsky N (1982) Growth and size structure in a Baltic Mytilus edulis population. Mar Biol 68:117-133

Madsen FJ (1954) On the food habits of the diving ducks in Denmark. Dan Rev Game Biol 2:157-266

Möller P, Rosenberg R (1983) Recruitment, abundance and production of Mya arenaria and Cardium edule in marine shallow waters, western Sweden. Ophelia 22:33-55

Nagy KA (1987) Field metabolic rate and food requirement scaling in mammals and birds. Ecol Monogr 57:111-128

Nehls G (1989) Occurrence and food consumption of the common eider, Somateria mollissima, in the Wadden Sea of Schleswig-Holstein. Helgol Meeresunters 43:385-393

Nilsson L (1980) Wintering diving duck populations and available food resources in the Baltic. Wildfowl 31:131-143

Rumohr H, Brey T, Ankar S (1987) A compilation of biometric conversion factors for benthic invertebrates of the Baltic Sea. Publ Baltic Mar Biologists 9

Stewart-Oaten A, Bence JR, Osenberg CW (1992) Assessing effects of unreplicated pertubations: no simple solutions. Ecology 73:1396-1404

Stott RS, Olson DP (1973) Food-habitat relationship of sea ducks on the New-Hampshire coastline. Ecology 54: 996-1007

Van Eerden MR (1984) Waterfowl movements in relation to food stocks. In: Evans PR, Goss-Custard JD, Hale WG (eds) Coastal waders and wildfowl in winter. Cambridge Univ Press, Cambridge, p 84-100

Vickery JA, Sutherland WJ, Watkinson AR, Lane SJ, Rowcliffe JM (1995) Habitat switching by dark-bellied brent geese Branta b. bernicla (L.) in relation to food depletion. Oecologia 103:499-508

Ydenberg R, Guillemette M (1991) Diving and foraging in the Common Eider. Ornis Scand 22:349-352

Zwarts L, Blomert AM, Wanink, JH (1992) Annual and seasonal variation in the food supply harvestable by knot Calidris canutus staging in the Wadden Sea in late summer. Mar Ecol Prog Ser 83:129-139

Submitted: September 2, 1999; Accepted: February 29, 2000 Proofs received from author(s): July 10, 2000 